\title{
Development of Inquiry Assisted Educational Video to Increase Students' Learning Independence in SMPLB Ungaran
}

\author{
Susi Agung Purwaningtyas ${ }^{1}$, Ani Rusilowati ${ }^{2}$ Fianti $^{3}$, Aninditya Dwi Perwitasari ${ }^{4}$ \\ 1,2,3,4Physics Education, Graduate School, Universitas Negeri Semarang, Indonesia \\ ${ }^{1}$ Coresponding email: Susipurwaningtyas@ gmail.com
}

\begin{abstract}
The purpose of this research is to develop an educational video worthy of use to develop self-reliance of deaf students in SMPLB Ungaran. Low student learning independence needs to be trained and enhanced because the primary purpose of Special School (SLB) is to produce an independent graduate. Another goal is to improve learning outcomes through inquiry assisted educational video developed specifically for children with hearing impairment. The method developed in this study refers to research and development methods. Data on cognitive learning outcomes obtained through the test. Results obtained by the independence of students develops and there is an increase in cognitive learning outcomes of deaf students in SMPLB Ungaran.
\end{abstract}

Keywords: Learning independence, deaf, educational videos

\section{Introduction}

Children with special needs are children with special characteristics and have abnormalities in physical, mental, and social behavior (Akram, 2013). Children's abnormalities cause barriers in the learning process that require different educational services in each child (Maftuhatin, 2014). One of the factors that hampers the learning process of children with special needs is the learning independence of students was lack, so they need more attention and assistance to develop self-reliance learning.

The observation results in the Ungaran State Extraordinary School (SLB) show that the class division in this school is different from normal school. Class division is divided into several categories according to the needs of students, namely: visual impairment, deaf, intellectually disabled, physically disabled, and autism. Students who have limited hearing impairments are grouped into deaf students classes. Deaf students also receive special treatment when learning activities. Deaf is a person who lacks or loses the ability to hear, partly or wholly as a result of the nonfunctioning part or all of the hearing instrument (Winarsih, 2010). Deaf students cannot use their hearing senses to the fullest. This problems make an impact on the child's language skills (Fusick, 2008). Children in the deaf class were classified into four categories, namely mild, moderate, severe, and very severe (Ashman and Elkins, 1994). Information obtained when observations at SMPLB Ungaran showed that students with hearing impairment grade VII amounted to 9 students and each was in the category of mild to moderate hearing. This is seen when students say greeting one by one, visible articulation of deaf students sound less clear.

The learning process outside the skill subjects at SMPLB Ungaran is not much use of instructional media. One example when the science-learning process teachers use only video that has not been specifically designed for deaf students so that students cannot use the video when no teacher is accompanying. According to Kemp and Dayton (1985) learning media for students with special needs should be tailored to the characteristics and needs of these students so that its useful.

Based on the problems that have been submitted, the researcher aims to develop a learning video designed specifically for deaf students in improving the independence of learning that accordance with the main objectives of SMPLB Ungaran.

\section{Methods}

The study of BISINDO-based learning video development (Indonesian Sign Language) to improve the independence and learning outcomes of deaf students was conducted at Ungaran State Extraordinary School in July 2018. The type of research used is research and development by Sugiyono (2015: 45) with several steps, that is : (1) research on existing products, (2) literature studies and field studies, (3) product development planning (design), (4) product creation, (5) product validation, (6) revisions I 
product, (7) initial test, (8) revision II product, and (9) product implementation.

Expert validation test is done by expert judgment to know the validity level of BISINDO based learning video (Indonesian Sign Language) developed. In this study, the validator or expert is a lecturer and teacher of SMPLB Ungaran which is considered to be competent. Lecturers involved in this validation include experts in the field of learning media, materials physics, and physics learning. Student self-reliance data obtained through the observation sheet and student learning outcomes obtained through a written test conducted after learning using BISINDO based learning video that has been developed.

\section{Results and Discussion}

The first phase of this study is to examine existing products to be known specifications, advantages and disadvantages of these products. The product that studied in this research is the learning video used in teaching and learning activities at SMPLB Ungaran. The second phase is conduct literature and field studies to find out the potential and problems that exist in Ungaran State Extraordinary School. Field study was conducted by observation and interview, while literature study was conducted by reviewing the related literature to learning instrument based on BISINDO (Indonesian Sign Language). Observations and interviews were conducted to obtain facts or findings in the field, including the curriculum used, the allocation of learning time, learning media used by teachers in science learning and knowing the students' abilities. Both stages are conducted to initiate the development of BISINDO based video to improve the independence and learning outcomes of deaf students. The next stage is the development planning and product development, after the product finished its will be implemented which is the last stage of the research. The product implementation stage is done after the initial trial process. The purpose of the initial trial is to determine the feasibility and weakness of the developed product.

In the initial test phase obtained data of self-reliance and student learning outcomes. Student self-reliance data obtained through the observation sheet and student learning outcomes obtained through a written test conducted after learning using video based
BISINDO that has been developed. Student cognitive learning outcomes are presented in Table 1.

Table 1. Student cognitive learning outcomes

\begin{tabular}{lccccccccc}
\hline & \multicolumn{1}{c}{ Number of Student } \\
& 1 & 2 & 3 & 4 & 5 & 6 & 7 & 8 & 9 \\
\hline Before & 6 & 4 & 5 & 4 & 5 & 4 & 5 & 4 & 5 \\
\multirow{4}{*}{ After } & 7 & 7 & 5 & 7 & 5 & 4 & 4 & 7 & 0 \\
& 7 & 6 & 7 & 6 & 7 & 7 & 6 & 7 & 6 \\
& 0 & 5 & 0 & 6 & 0 & 0 & 7 & 0 & 6 \\
\hline
\end{tabular}

The results of the analysis revealed that the cognitive learning outcomes of deaf students SMPLB Ungaran on the subjects' temperature and measurement are good. In Table 1, it can be seen that there is an increase in student learning outcomes before and after learning with a video-based inquiry model based on BISINDO. This result is in accordance with the statement from Luginbuhl (2010) that the inquiry approach emphasizes the students' critical thinking skills. The improvement of students' cognitive learning outcomes is also due to the use of BISINDO-based video media that suits to children needed with hearing impairment. The results of research conducted by Suhandi (2008) that learning using simulation can improve concept understanding.

Student self-reliance data obtained through observation sheet. Table 2 presents data on student self-reliance.

Table 2. Independence of Student Learning

\begin{tabular}{cccc}
\hline No & Category & Before & After \\
\hline 1 & Good & 2 & 4 \\
& & Students & Students \\
2 & Enough & 1 & 2 \\
& & Students & Students \\
3 & Not Good & 5 & 3 \\
& & Students & Students
\end{tabular}

Physical learning of temperature and videoaided material based on BISINDO, shows that students learning independence has increased. This can be seen from Table 2 that the number of students in the good category and good enough are increase at the final code and the number of students in not good category there 
is decrease. Increased student self-reliance occurs because students become interested and feel helped by the video-based learning assistant BISINDO. The results of research conducted by Mursita (2015) with the subject of 100 hearing impairment people from various regions in Indonesia is as much as 3\% disagree using of BISINDO in communication, $6 \%$ quite agree, $43 \%$ agree. The reason for the acceptance of BISINDO because it contains the appropriate expression and easy to understand statement obtained from the results of interviews with the deaf.

\section{Conclusion}

Implementation of BISINDO based video on temperature and measurement materials can increasing the independence and learning outcomes of students of Deaf School of SMPLB Ungaran.

\section{References}

Akram, B. (2013). Scientific Concepts of Hearing and Deaf Students of Grade VII. Journal of Elementary Education, 23(1): 1-12.

Maftuhatin, L. (2014). Evaluasi Pembelajaran Anak Berkebutuhan Khusus (ABK) di Kelas Inklusif di SD Plus Darul Ulum
Jombang. Jurnal Studi Islam, 5 (2): 210.

Winarsih, M. (2007). Intervensi Dini Bagi Anak Tunarungu dalam Pemerolehan Bahasa. Jakarta: Departemen Pendidikan dan Kebudayaan. Direktorat Jenderal Pendidikan Tinggi.

Fusick, L. (2010). Serving clients with hearing loss: best practices in mental health counseling. Journal of Counseling and Development. 86(1):102

Ashman, A., \& Elkins, J. (2015). Education For Inclusion and Diversity 5th Edition. Melbourne: Pearson Australia.

Luginbuhl, L. (2010). Self-Monitoring to Minimize Student Resistance to Inquiry. Journal of Physics Teacher Education, 5(3): 11-23.

Suhandi. (2008). Efektifitas Penggunaan Media Simulasi Virtual Pada Pendekatan Pembelajaran Konseptual Interaktif Dalam Meningkatkan Pemahaman Konsep dan Meminimalkan Miskonsepsi. Laporan Penelitian: LP2M Universitas Pendidikan Indonesia

Mursita, R. (2015). Respon Tunarungu Terhadap Penggunaan Sistem Bahasa Isyarat ( SIBI) dan Bahsa Isyarat Indonesia (BISINDO) dalam Komunikasi. Inklusi, 2(2). 